\title{
МІСЦЕ ВЧЕННЯ ПРО ПОТЕРПЈЛОГО ВІД КРИМІНАЛЬНОГО ПРАВОПОРУШЕННЯ В СИСТЕМІ НАУК КРИМІНАЛЬНО-ПРАВОВОГО ЦИКЛУ
}

\author{
ЛАДАНІВСЬКА Наталія - Донецький юридичний інститут МВС України \\ здобувачка кафедри кримінально-правових дисциплін \\ ORSID. org/0000-0002-8517-2842 \\ УДК 343.2:211.3 \\ DOI 10.32782/NP.2020.4.15
}

\begin{abstract}
У статті автор робить спробу з'ясувати ставлення представників наук кримінальноправового изиклу до деббініцій та ролі потерпілого від кримінального правопорушення. Доводиться, щзо у більшості випадків потерпілий иікавить учених з точки зору процесу розслідування та доказування або як антипод кримінального правопорушника. Акцентується увага на тому, що лише кримінальне право розглядає особу, яка постраждала від суспільно небезпечного діяння як об'єкт захисту конституиійно закріплених прав, свобод, иінностей та відшкодування матеріальноӥ та моральноӥ шкоди. Підсумовується, що наразі існує необхідність у законодавчому закріпленні в чинному Кримінальному кодексі України статусу потерпілого від кримінального правопорушення, котре вдало б корелювалось із суміжними галузями наукового знання.
\end{abstract}

Ключові слова: потерпілий, кримінальне правопорушення, кримінальне законодавство, кримінальне прочесуальне законодавство, кримінологія, криміналістика, науки кримінально-правового ицклу.

На сьогодні науки кримінально-правового циклу стрімко розвиваються, що можна пояснити творчими пошуками причин, умов та шляхів подолання кримінальнопротиправної діяльності. Однак, незважаючи на плідну працю вчених та законотворців, низка проблемних питань залишається актуальною. Однією з таких проблем є визначення місця та ролі потерпілого від кри- мінального правопорушення. Варто зауважити, що доктринальні підходи спеціалістів-теоретиків у різних галузях юридичних наук до феномену потерпілого якісно відрізняються, а у деяких науках (наприклад, у кримінальному праві) взагалі до сьогодні відсутні майже будь-які згадування. Такий стан справ є несприятливим у контексті боротьби із суспільно небезпечними діяннями та гальмує розвиток вітчизняного законодавства. Отже, враховуючи вказане, вважаємо за доцільне зупинитись більш детально на визначенні місця вчення про потерпілого від кримінального правопорушення в системі наук кримінально-правового циклу.

Відтак, однією з наук, яка приділила повноцінну увагу потерпілому від кримінального правопорушення $\in$, звичайно, кримінальне процесуальне право. Це не є дивним, оскільки саме для останнього протилежна сторона суспільно небезпечного діяння визначає курс майбутньої процедури досудового та судового розслідування. «У ст. 3 КПК термін «потерпілий» віднесено до основних термінів, який позначає учасника кримінального провадження як однієї із сторін кримінального провадження 3 боку обвинувачення. Разом 3 тим, уже тут можна відзначити суперечливість визначень. Так, у п. 19 ст. 3 потерпілого названо в складі сторони кримінального провадження на боці обвинувачення, а у п. 25 «потерпілий» визначений як окремий «учасник кримінального провадження» поряд із сторонами; так само у п. 26 «потерпілий» визна- 


\section{Кримінальне право, кримінальний процес та криміналістика}

чений як «учасник судового провадження» поряд із сторонами, а не в складі сторони. Це свідчить про недостатньо визначений процесуальний статус потерпілого» [1, с. 107].У цьому контексті хочемо зазначити, що нам більш близька думка про те, що потерпілий - це самостійна сторона кримінального провадження, оскільки віднесення його до позиції обвинувачення дещо звужує межі самого поняття такої особи. Ми вважаємо, що особа, котра постраждала від суспільно небезпечного діяння та безпосередньо суб'єкт останнього не повинні відноситись до сторін провадження, оскільки воно все ж таки є процедурою юридичною, а отже, саме юристи мають його представляти.

На думку П.Л. Слободянюка, «у п. 3 ст. 19 потерпілий помилково вказаний у складi сторони обвинувачення, оскільки він не $є$ суб'єктом кримінально-правового відношення, як основного матеріального правовідношення щодо кримінального процесу... Але ця суперечність виявляє себе у непослідовності інших статей КПК, зокрема, у ст. 22, присвяченій змагальності сторін у судовому провадженні. Хоча п. 26 ст. 3 КПК потерпілий не віднесений до «сторони», він може підтримувати обвинувачення в окремих випадках, передбачених КПК. Так само, поряд iз сторонами вказано потерпілого у частині третій ст. 89 КПК. Тому виникає питання про справжній процесуальний статус потерпілого: потерпілий 6 «стороною» судового провадження чи іншим його «учасником», можливо, «заінтересованою особою» 3 особливим статусом?» [1, с. 107]. Що стосується визначених ученим дефініцій, хочемо дещо зупинитись $з$ метою висловлювання власної думки. Відтак, розгляд потерпілого як зацікавленої особи з особливим статусом 6 , як здається, не зовсім правильним. Зацікавленою особою в межах кримінального провадження може вважатись майже кожен його учасник, оскільки слідчий зацікавлений у позитивному завершенні розслідування, адвокат - у сприятливій для захисту обстановці, правопорушник - у тому, щоб усе завершилось на його користь тощо. У всіх цих осіб є також свій «особливий» статус. Віднесення до сторони обвинувачення, як ми вище вказали, також є помилковим. Тому, на нашу думку, у межах кримінального процесу потерпілий є учасником кримінального провадження, зацікавленим у відновленні справедливості та його порушених прав i свобод, а також відшкодування завданої кримінальним правопорушенням шкоди.

Зокрема, «за ст. 25 КПК кримінальне провадження має публічно-правовий характер і передбачає обов'язок прокурора, слідчого розпочати його. Але разом 3 тим воно не може бути розпочате в окремих випадках без заяви потерпілого (кримінальне провадження у формі приватного обвинувачення), а відмова потерпілого від обвинувачення у випадках, передбачених КПК, є безумовною підставою для його закриття (ст. 26 КПК). Процесуальні права потерпілого на захист його майнових прав не залежать від участі його представника в кримінальному провадженні (ст. 20 КПК). Потерпілий, нарівні 3 підозрюваним, обвинуваченим, іншими особами, права чи інтереси яких обмежуються під час досудового розслідування, має право звернутися до прокурора, слідчого судді, суду з клопотанням стосовно скорочення строків провадження або окремих процесуальних дій порівняно 3 визначеними Кодексом (ст. 28 КПК). Так само, нарівні з обвинуваченим і прокурором, потерпілий може заявляти клопотання про направлення кримінального провадження до іншого суду (ст. 34 КПК). Слід підкреслити, що у ст. 55 КПК закріплено нормативне визначення не потерпілого «взагалі», а «потерпілого у кримінальному провадженні»; ним визнається «фізична особа, якій кримінальним правопорушенням завдано моральної, фізичної або майнової шкоди, а також юридична особа, якій кримінальним правопорушенням завдано майнової шкоди». При цьому права і обов'язки потерпілого виникають в особи «з моменту подання заяви про вчинення щодо неї кримінального правопорушення або заяви про залучення її до провадження як потерпілого» [1, с. 108]. Таким чином, можемо підсумувати, що в межах кримінального процесуального права потерпіла особа розглядається у вузькому розумінні, саме як учасник кримінального провадження. При цьому варто зауважити, що така особа наділена аналогічними пра- 
вами, як і правопорушник та інші сторони. Поряд із кримінальним процесом достатньо цікаву позицію з точки зору вчення про потерпілого займає криміналістика, котра, на нашу думку, є своєрідною «дочірньою» наукою.

Так, для криміналістики знання про потерпілу особу дозволяє правильно сформулювати алгоритм процесу розслідування та встановлення фактів, необхідних для завершення картини кримінального правопорушення. На відміну від того самого кримінального процесу, криміналістів цікавлять не порушені права людини і не обсяг шкоди, яка була їй завдана, а саме ті факти, котрі здатні пояснити мотивацію правопорушення. Учені правильно вказують, що «... для того, щоб розроблена теоретиками криміналістична характеристика злочину змогла допомогти практикам у розслідуванні конкретних кримінальних правопорушень, до ії складу слід включати не всі, а лише значущі елементи. Одним із таких елементів, безспірно, є особа потерпілого, адже відомості про нього або ж інформація, надана ним, можуть бути використані під час висунення слідчих версій, планування початкового та подальшого етапів розслідування, розроблення заходів криміналістичної профілактики тощо. Загалом, актуальність та практична корисність дослідження особи потерпілого детермінували появу віктимологічного підходу у криміналістиці, відповідно до якого збирання інформації про злочинця розпочинається саме 3 дослідження особи та поведінки потерпілого» [2, с. 46]. Отже, у цьому контексті ми можемо сказати, що в межах знання про особу потерпілого, криміналістика використовує знання, котрі $\epsilon$ надбанням віктимологічної науки, котру цікавлять фізіологічні, соціальні та психологічні поведінкові особливості людини, які обумовлюють обрання саме іiі як жертви кримінального правопорушення.

Саме тому, вивчаючи особу потерпілого, криміналісти, як і віктимологи «виділяють дві групи відомостей: 1) відомості про власні якості, притаманні потерпілому як особистості, яка наділена певною сукупністю фізичних та соціально-психологічних рис;2) відомості про особливості поведінки, зв’язки та взаємини потерпілого зі злочинцем та іншими особами, його місце в системі найближчого соціального оточення, що може зумовити специфіку вчинення злочину (спосіб, час, місце, знаряддя та засоби, інші обставини його вчинення) [3, с. 52]. Такими відомостями, на думку Ю. В. Гавриліна та М. Г. Шурухнова, є демографічні дані (стать, вік, місце проживання, професія тощо), інформація про характер та розмір завданої потерпілому шкоди, фізичні, біологічні та психологічні особливості потерпілого, його спосіб життя, захворювання, віктимність поведінки, рівень культури, ціннісні орієнтації, взаємозв'язки з іншими людьми» [4, с. 56]. «Також у результаті криміналістичного дослідження особи жертви злочину (потерпілого) мають бути з'ясовані: дані, які характеризують таку особу як особистість; дані про спосіб життя, зв'язки та стосунки 3 оточенням; дані про взаємини зі злочинцем; особливості поведінки потерпілого до й під час вчинення злочину; характер шкоди, наслідки злочину; позиція потерпілого у кримінальному проваджені» [5, с. 21]. Таким чином, можна сказати, що вчених-криміналістів цікавить саме біологічна та соціальна позиція потерпілого від кримінального правопорушення, його взаємозв'язки, матеріальне становище тощо. У межах досліджуваної нами науки сама людина сприймається як рушійна сила протиправного діяння. Саме тому, розпочинаючи розгляд криміналістики, ми вказали, що вона $е$ «дочірньою» наукою, оскільки допомагає кримінальному процесу. При цьому мова йде взагалі про розділ, присвячений криміналістичній тактиці та методиці розслідування, оскільки криміналістична техніка взагалі далека від потерпілого та його інтересів.

В.Ю. Шепітько розширює вищевказаний перелік та зазначає, що «вивчення особи потерпілого повинно включати в себе: 1) відомості анкетного характеру (стать, вік, місце народження, роботи або навчання, стаж, професія (фах), сімейний стан, наявність родичів); 2) соціально-психологічні дані (тип темпераменту, риси характеру, емоційні прояви, особливості взаємодії (спілкування) в колективі); 3) особливості поведінки - до злочинної події, у момент вчинення злочи- 


\section{Кримінальне право, кримінальний процес та криміналістика}

ну, після його вчинення; 4) незалежні характеристики (за місцем роботи чи навчання, за місцем проживання, за показаннями рідних, близьких чи найближчого оточення); 5) соціальні зв’язки (коло спілкування, найближчі знайомі, особливості проведення вільного часу, наявність або відсутність спільного бізнесу, комерційна діяльність, специфіка групової поведінки, бажання вступити в певні мікрогрупи); 6) дані про суспільнокорисну діяльність, її особливості; 7) матеріальне становище (наявність майна, в тому числі і нерухомості, грошових вкладів, джерело збагачення, наявність або відсутність боргових зобов'язань, отримання кредитів і можливість їх погашення);8) злочинний досвід (наявність або відсутність судимостей, зв'язки 3 кримінальними угрупованнями, дружні стосунки з особами, які притягувалися до кримінальної відповідальності); 9) причини віктимної поведінки (виконання певних професійних функцій; соціальна деформація особистості) тощо» [6, с. 164-165]. Таким чином, для криміналістики, як, до речі, і для кримінології, вчення про потерпілого має факультативне значення, котре допомагає теоретикам та практикам досліджувати кримінальне правопорушення з усіх боків у тісній взаємодії його елементів. Варто вказати, що вчення про потерпілого в науках кримінально-правового циклу не $є$ в повній мірі популярним, оскільки останній, здебільшого, присвячений особі кримінального правопорушника. Це стосується і такої науки, як кримінальновиконавче право, котре розглядає особливості призначення тих чи інших заходів кримінально-правового впливу та виправлення особи, яка вчинила протиправне діяння. Взагалі, більш прикладні кримінально-правові науки, такі як кримінальне процесуальне, кримінально-виконавче та, навіть, безпосередньо - кримінальне право майже не приділяє увагу дефініції та ролі потерпілого в кримінальному правопорушенні. Такий стан справ, на нашу думку, можна пояснити тим фактом, що ці науки напряму пов’язані iз процесом виявлення, перевиховання та ресоціалізації кримінального правопорушника, виконання основного завдання, котре поставлене перед сучасним кримінальним правом. Саме тому сьогодні максимум уваги жертві приділяється виключно віктимологами. Однак, ми впевнені, що якщо відсутність теоретичних положень щодо потерпілого в криміналістиці, кримінальному процесуальному та кримінально-виконавчому праві не є фатальною прогалиною, то що стосується кримінального права - ситуація потребує нагального вирішення.

«Аналіз статей чинного Кримінального кодексу України (далі - КК України) [7] свідчить про те, що в ньому поняття «потерпілий» використовується не так у процесуальному значенні, як у більш широкому розумінні соціального статусу потерпілого від злочину (кримінологічному значенні). Так, наприклад, у ст. 37 КК надано визначення уявної оборони, якою визнаються «дії, пов'язані із заподіянням шкоди за таких обставин, коли реального суспільно небезпечного посягання не було, і особа, неправильно оцінюючи дії потерпілого, лише помилково припускала наявність такого посягання». У цьому випадку термін «потерпілий» означає особу, дії якої помилково сприйняті іншою особою як злочинні і у відповідь на які вказаній особі заподіяно шкоди. Так само згідно зі ст. 38 КК не визнаються злочинними дії потерпілого та інших осіб безпосередньо після вчинення посягання, спрямовані на затримання особи, яка вчинила злочин, і доставлення ії відповідним органам влади, якщо при цьому не було допущено перевищення заходів, необхідних для затримання такої особи. Тут термін «потерпілий» позначає не процесуальний, а соціальний статус особи, оскільки йдеться про дії безпосередньо після вчинення посягання на права цієї особи, коли ще не розпочато кримінального провадження і особу формально не визнано потерпілою від злочину» [1, с. 115]. Отже, в контексті зазначених статей кримінального законодавства потерпілий розглядається 3 точки зору людини, якій завдається шкода, тобто потерпілий - об'єкт захисту кримінального законодавства.

«Кримінальне законодавство передбачає i такі випадки, коли потерпілий може зазнати шкоди від злочину, за який особа, що його скоїла, не нестиме кримінальної відповідальності. Зокрема, згідно зі ст. 43 КК осо- 
ба, яка виконувала спецзавдання з попередження чи розкриття злочинної діяльності організованої групи чи злочинної організації, несе кримінальну відповідальність тільки за вчинення у складі організованої групи чи злочинної організації особливо тяжкого злочину, вчиненого умисно і поєднаного 3 насильством над потерпілим, або тяжкого злочину, вчиненого умисно і пов'язаного зі спричиненням тяжкого тілесного ушкодження потерпілому або настанням інших тяжких або особливо тяжких наслідків. Тобто за шкоду, завдану іншими злочинами потерпілому, така особа не відповідає, і необхідно було б вказати про відповідальність держави за завдану людині шкоду у цих випадках» [1, с. 115]. Цікавим, на нашу думку, є той факт, що окремі норми Загальної частини кримінального законодавства під потерпілим апріорі розуміють фізичну особу, тобто людину.

«Також не виключно у процесуальному значенні використовується термін «потерпілий» у ст. 46 КК. Згідно з цією статтею особа, яка вперше вчинила злочин невеликої тяжкості або необережний злочин середньої тяжкості, крім корупційних злочинів, звільняється від кримінальної відповідальності, якщо вона примирилася з потерпілим та відшкодувала завдані нею збитки або усунула заподіяну шкоду. Наприклад, ситуація, коли сталася ДТП і винна в ній особа на місці розрахувалася за завдані збитки та примирилася 3 потерпілим. У такому випадку вказана особа звільняється від кримінальної відповідальності, якщо стосовно неї буде розпочате кримінальне провадження за заявою якоїсь іншої особи, а потерпілий не дає згоди на залучення його в це провадження i, отже, не отримує процесуального статусу потерпілого. У кримінологічному, а не процесуальному значенні використано термін «потерпілий» у ст. 67 КК, згідно 3 якою однією 3 обставин, які обтяжують покарання, є вчинення злочину у зв'язку 3 виконанням потерпілим службового або громадського обов'язку. Відповідно до КПК процесуальний статус усіх потерпілих не залежить від виконання ними службових тощо обов'язків. Оскільки вказані норми вміщені у Загальній частині КК, можна вважати, що і в його Особливій частині при встановленні кримінальної відповідальності в конкретних статтях, пов'язаної з потерпілим, термін «потерпілий» вживається у кримінологічному, а не процесуальному значенні» [1, с. 116]. Отже, наведені приклади свідчать про те, що в кримінальному законодавстві підхід до потерпілого носить, здебільшого, кримінологічний характер, тобто як до особи, яка протиставляється кримінальному правопорушнику.

Таким чином, на сьогодні вчення про потерпілого не є актуальним для представників наук кримінально-правового циклу. Звичайно, в кожній із розглядуваних доктрин так чи інакше приділяється увага особі, яка постраждала від кримінального правопорушення, однак у тих межах, котрі допустимі та мають для неї значення. Нами було встановлено наступне: 1) у кримінальному процесуальному праві потерпілий наразі сприймається як одна із сторін обвинувачення. При цьому спеціалісти розглядають досліджуваний нами феномен у вузькому розумінні, виключно в межах кримінального провадження; 2) криміналістика в контексті вчення про особу потерпілого межує із віктимологією та кримінологією (особливо, якщо розглядати віктимологію як науку, штучно вилучену із кримінології). Криміналістів особа, яка потерпіла від кримінального правопорушення, цікавить тільки як відправна точка самого протиправного діяння, скоріше - як доказова база, котра допомагає в розслідуванні; 3) кримінальне право згадує потерпілого лише в окремих нормах Загальної та Особливої частини Кодексу, не маючи жодного універсального підходу до дефініції та його ролі в законодавстві. Саме кримінальне законодавство, на відміну від інших, потерпілий має цікавити 3 точки зору захисту його прав, свобод і цінностей як матеріальних, так і моральних.

\section{入iтература \\ 1. Слободянюк П.А. Судовий за- хист потерпілих як юридична гарантія прав людини в Україні: дис. канд. юрид. наук : 12.00 .02 - конституційне право; муніципальне право. НАН України, Ін-т}


держави і права ім. В. М. Корецького. Київ, 2019. 233 с.

2. Журавель В. А. Допрос потерпевшего при виктимном поведении. Криминалистика и судебная экспертиза. Вып. 26. К. : Вища шк., 1983. С. 46-51.

3. Сокол Е. В. Особенности личности несовершеннолетнего, вовлеченного в совершение преступления. Вестник Краснодарского университета МВД России. 2009. № 4.C. $50-55$

4. Гаврилин Ю. В. Криминалистика: методика расследования отдельных видов преступлений : курс лекций / Ю.В.Гаврилин, Н. Г. Шурухнов. М., 2004. 471 с.

5. Бурданова В. С. Виктимологические аспекты криминалистики : учеб. пособ. / В. С. Бурданова, В. М. Быков. Ташкент : Изд-во Ташк. ВШІ МВД СССР, 1981. 79 с.

6. Шепітько В. Ю. Особа потерпілого в системі криміналістичної характеристики злочинів. Проблеми законності : республік. між від. наук. зб. / відп. ред. В. Я. Тацій. Х.: Нац. юрид. акад. України, 2008. Вип. 93.С. $168-174$.

7. Кримінальний кодекс України від 05.04.2001 р. № 2341-III (редакція від 10.11 .2018 р.). URL: https://zakon.rada.gov. ua/laws/show/2341-14/ed20181110 (дата звернення: 20.12.2018).

\section{THE PLACE OF STUDY ABOUT THE VICTIM OF CRIMINAL OFFENSE IN THE SYSTEM OF SCIENGES OF THE CRIMINAL LAW GYCLE}

In the article, the author tries to find out the attitude of the representatives of the science of the criminal law cycle to the definition and role of the victim of a criminal offense. It turns out that in most cases, the victim is of interest to scientists in terms of the process of investigation and evidence or as the antithesis of a criminal offender. Emphasis is placed on the fact that only criminal law considers a person who has suffered from a socially dangerous act as an object of protection of constitutionally enshrined rights, freedoms, values and compensation for material and moral damage. It is concluded that at present there is a need to legislate in the current Criminal Code of Ukraine the status of a victim of a criminal offense, which would be successfully correlated with related fields of scientific knowledge.

Key words: victim, criminal offense, criminal legislation, criminal procedural legislation, criminology, criminology, sciences of the criminal law cycle. 